The following periodicals:

Journal of Historical Archaeology

Journal of the Académie Internationale de la Pipe

Knasterkopf

Pijpelogische Kring Nederland

Post-Medieval Archaeology

\section{Cleere, Henry}

\section{Willem J. H. Willems}

ICOMOS International Scientific Committee

on Archaeological Heritage Management

(ICAHM), Faculty of Archaeology,

Leiden University, Leiden, Netherlands

\section{Basic Biographical Information}

Professor Henry Cleere was born in December 1926 in Croydon, UK. After military service in Italy, Egypt, and Palestine, he pursued a career in the iron and steel industry before becoming involved with archaeology in 1974, as director of the Council for British Archaeology. By then, he had also obtained his Ph.D. for a thesis on the iron industry of Roman Britain. The 1970s was the heyday of rescue archaeology in Europe, and he became involved in addressing some of the consequences for the profession. One development in the UK was the formation - formally started in 1979 - of what is currently the Institute for Archaeologists (IfA), a professional organization with a code of conduct. Cleere was one of those involved and who developed an interest in archaeological heritage management, from its principles and legal foundations to its organizational and practical applications.

\section{Major Accomplishments}

In 1979, he was awarded a Churchill Fellowship that enabled him to study the systems in a number of European countries and build a network in Europe. That led to a book he edited in 1984 called Approaches to the Archaeological
Heritage (Cambridge), which became very influential. It presented for the first time the management of archaeological resources in a comparative international context. The book was instrumental in discussions in the heritage sector in Europe in the 1980s that in turn led to a decision by the Council of Europe to revise the existing rather obscure treaty on archaeological heritage into what became the Convention of Malta in 1992. By then, Cleere had already published a second important book, extending to many more countries, Archaeological Heritage Management in the Modern World (London 1989).

Between 1981 and 1990, Henry Cleere was a member of the Board of ICOMOS, the International Council on Monuments and Sites, and in 1984 established that organization's International Committee on Archaeological Heritage Management (ICAHM). He was a prime mover in the drafting of the 1990 ICOMOS Charter on Archaeological Heritage Management. This was the first time the aims and responsibilities of archaeological heritage management, which were later also echoed in the Malta Convention, were defined internationally.

After his retirement from the CBA in 1991, Cleere started a third career as World Heritage coordinator for ICOMOS in Paris. ICOMOS is the advisor on cultural heritage to the UNESCO World Heritage Committee, and for 10 years, he carried out evaluation and monitoring missions to many sites now on the World Heritage List. Given his experience in international organization and legislation, he was also asked to become involved in the founding committee of the European Association of Archaeologists (EAA) and in 1994 became its first secretary. He also led the working party that brought into being the "EAA Code of Practice" in 1997 and was editor of the newsletter The European Archaeologist until 2002.

In 1998 Henry Cleere became honorary professor at the Institute of Archaeology at UCL, and in 2002 he received the fourth European Heritage Prize in recognition of his work. 


\section{Cross-References}

- Heritage and Archaeology

- Heritage and Public Policy

- Heritage Legislation, The Introduction of: Disciplining Through Law

- Heritage, Changing Views of: A Legal Perspective

- Immovable Heritage: Appropriate Approaches to Archaeological Sites and Landscapes

- International Committee on Archaeological Heritage Management (ICAHM) (Cultural Heritage Management)

- International Council on Monuments and Sites (ICOMOS): Scientific Committees and Relationship to UNESCO

- UNESCO's World Heritage List Process

\section{References}

CleERE, H. (ed.) 1984. Approaches to the archaeological heritage. Cambridge: Cambridge University Press.

- 1989. Archaeological heritage management in the modern world. London: Unwin Hyman Ltd.

\section{Further Reading}

CleERE, H. 1970. Iron smelting in a reconstructed Roman furnace. London: The Iron and Steel Institute.

- 1993. British archaeology in a wider context, in J. Hunter \& I. Ralston (ed.) Archaeological resource management in the UK. An introduction: 115-24. Phoenix Mill: Alex Sutton Publishing Ltd.

- 1995. Cultural landscapes as world heritage. Conservation and Management of Archaeological Sites 1: 63-8.

- 1996. The concept of 'outstanding universal value' in the World Heritage Convention. Conservation and Management of Archaeological Sites 4: 227-33.

- 2000. The World Heritage Convention in the Third World, in F.P. Mcmanomon \& A. Hatton Cultural resource management in contemporary society. Perspectives on managing and presenting the heritage: 99-106. London: Routledge.

Cleere, H. \& D. Crossley. (ed.) 1985. The iron industry of the Weald. 2nd edn, 1995. Leicester: Leicester University Press.

Cleere, H. \& J. du Plat Taylor. (ed.) 1978. Roman shipping and trade: Britain and the Rhine Provinces (Council for British Archaeology Research Report 25). London: Council for British Archaeology.

Cleere, H., J. G. Evans \& S. Limbrey. (ed.) 1975. The effect of man on the landscape: the Highland Zone (Council for British Archaeology Research Report 11). London: Council for British Archaeology.

\section{Clegg, John K.}

Jo McDonald $^{1}$ and Kate Sullivan ${ }^{2}$

${ }^{1}$ Centre for Rock Art Research + Management, University of Western Australia, Crawley,

WA, Australia

${ }^{2}$ Kate Sullivan and Associates Pty Ltd, Balmain, NSW, Australia

\section{Basic Biographical Information}

John Clegg was born on January 11th, 1935 in Nottingham, UK.

He grew up in Cambridge, England, where his mother was an academic. During World War II (aged 5-8), John and his sister were evacuated to stay with an aunt in Vancouver, Canada. During these early years began his lifelong interest in sculpture. Upon his return, John attended The Leys School in Cambridge. He graduated from Magdalene College, Cambridge, with a B.A. Honors and Certificate in Education in 1959. He received an M.A. Honors in 1962 from the same university. He had read Geography for two years before changing to Archaeology through which he went on several excavations and was influenced by both Eric Higgs and Charles McBurney. After working as a school teacher, he worked as a contract archaeologist between 1963 and 1964, excavating Coygan Cave in South Wales. He moved to Brisbane, Australia, in 1964, taking up a post in the Psychology Department (in which Archaeology was located), University of Queensland. He soon moved to Sydney, where while studying sculpture at what was later to become the National Art School, he held various positions at the Department of Anthropology and later in Classics and Archaeology at Sydney University. Over a 25-year period at Sydney University, he taught hundreds of students how to see, look at, and analyze rock art.

\section{Major Accomplishments}

John's Master's thesis (Mathesis Words, Mathesis Pictures, 1978), which analyzed the 